\title{
STEROIDAL GLYCOSIDES FROM VERONICA CHAMAEDRYS L. PLANTS. THE STRUCTURES OF CHAMAEDROSIDES A, B, C AND E.
}

\author{
Alexandra Marchenko ${ }^{1 *}$, Pavel Kintia ${ }^{1}$ and Bożena Wyrzykiewicz ${ }^{2}$ \\ ${ }^{1}$ Institute of Genetics and Physiology of Plants, Academy of Sciences of Moldova, \\ Padurii 20, 2004, Chisinau, Moldova \\ ${ }^{2}$ Adam Mickiewicz University in Poznan, Grunwaldzka 6, 60-780 Poznań, Poland \\ *lexmarcenco@mail.ru,tel.37322 555259,fax37322556180
}

\begin{abstract}
Four steroidal glycosides, named by us chamaedrosides, where two are new steroidal glycosides, have been isolated from the plants of Veronica chamaedrys L. (Scrophulariaceae) for the first time and their structures have been elucidated. Complete assignments of the $1 \mathrm{H}$ and 13C NMR chemical shifts for these glycosides were achieved by means of one- and two-dimensional NMR techniques, including 1H-1H COSY, HSQC, HMBC and ROESY spectra.
\end{abstract}

Keywords: steroidal glycoside, NMR analysis, Veronica chamaedrys $L$.

\section{Introduction}

The genus Veronica (Scrophulariaceae), which is widely distributed in Europe and Asia, especially in the Mediterranean area, is represented by 32 species in Republic of Moldova [1, 2]. Several Veronica species are used for the treatment of cancer, influenza, hemoptysis, laryngopharyngitis, hernia, and against cough, respiratory diseases plus as an expectorant and antiscorbutic in different countries [3-5]. As it was reported earlier, Veronica species contain steroidal glycosides, phenylethanoid and iridoid glycosides [6-13].

In the course of our phytochemical studies on the plant Veronica chamaedrys $L$. we had previously reported phenylethanoid and iridoid glycosides [14]. This paper describes the structural elucidation of the steroidal glycosides isolated from Veronica chamaedrys $L$. plants on the basis of extensive spectral analysis, including 2D NMR spectral data and chemical evidences.

\section{Results and Discussion}

The water extract of plants of Veronica chamaedrys $L$. was successively subjected to Sephadex gel filtration and silica gel column chromatography to afford four steroidal glycosides, named by us chamaedroside A (1), chamaedroside B (2), chamaedroside C (3) and chamaedroside E (4). All isolated compounds gave positive Sannie test [15], and compound 2 and 4 - positive Ehrlich test [16]. All compounds have been isolated as amorphous powders. Their structures were determined by corresponding shifts of ${ }^{1} \mathrm{H}$ and ${ }^{13} \mathrm{C}$ NMR spectral data.

The ${ }^{1} \mathrm{H}$ NMR spectrum of $\mathbf{1}$ displayed signals due to four steroidal methyl groups at $\delta 0.89(3 \mathrm{H}, \mathrm{s}, \mathrm{H}-18), 1.1$ $(3 \mathrm{H}, \mathrm{s}, \mathrm{H}-19), 1.5(3 \mathrm{H}, \mathrm{d}, \mathrm{J}=6.7 \mathrm{~Hz}, \mathrm{H}-21), 1.19(3 \mathrm{H}, \mathrm{d}, \mathrm{J}=6.7 \mathrm{~Hz}, \mathrm{H}-27)$, two methine proton signals at $\delta 4.30$ $(1 \mathrm{H}, \mathrm{m}, \mathrm{H}-3)$ and $4.98(1 \mathrm{H}, \mathrm{m}, \mathrm{H}-16)$ indicative of secondary alcoholic functions, two methylene proton signals at $\delta 4.128(1 \mathrm{H}, \mathrm{m}, \mathrm{H}-26 \mathrm{~b})$ and $3.48(1 \mathrm{H}, \mathrm{m}, \mathrm{H}-26 \mathrm{a})$, ascribable to a primary alcoholic function, and signals for the one anomeric at $\delta 4.98(1 \mathrm{H}, \mathrm{d}, \mathrm{J}=7.07 \mathrm{~Hz}) .{ }^{13} \mathrm{C}$-NMR signals due to a total of 27 carbon signals originating from the sapogenol were composed of four methyl groups at $\delta 16.5,16.3,23.9$ and 17.3, one oxygen bearing methine carbon at $\delta 77.6(\mathrm{C}-3)$, three quaternary carbons at $\delta 35.9(\mathrm{C}-10), 110.5(\mathrm{C}-22)$ and $40.5(\mathrm{C}-13)$, six methine carbons at $\delta 35.4(\mathrm{C}-8), 36.6(\mathrm{C}-5), 40.4(\mathrm{C}-9), 56.3(\mathrm{C}-14), 81.1(\mathrm{C}-16), 63.7$ (C-17), eleven methylene carbons at $\delta 21.3$ (C-11), 30.5 (C-2), 37.0 (C-1), 32.4 (C-7), 27.1 (C-6), 34.9 (C-4), 40.2 (C-12), 32.3 (C-15), 36.6 (C-23), 28.3 (C-24), 65.4 (C-26). On the basis of the HSQC and HMBC correlations, the aglycone moiety of chamaedroside

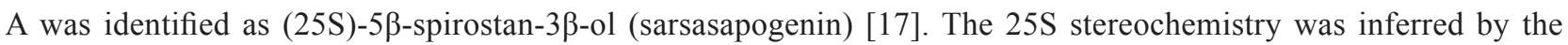
resonance of $\mathrm{H}-27$ methyl protons at $\delta 1.19$, a few bigger than 1.00, and also by the resonance difference between equatorial proton signal $(3.48, \mathrm{dd}, \mathrm{J}=6.5,9.5 \mathrm{~Hz})$ and axial proton signal $(4.128, \mathrm{~m})$ of $\mathrm{H}-26: 0.648 \mathrm{ppm}$, a few bigger than $0.57 \mathrm{ppm}$ [18]. $5 \beta$ configuration was deduced by HMBC correlation between the methyl signal at $\delta 1.1$ (Me-19) and carbon resonances at $\delta 40.4$ (C-9), 36.6 (C-5) and 37.0 (C-1) [18]. Using a combination of 1D-TOCSY and DQFCOSY spectral analysis, the sugar chain has been identified to be composed of one unit of $\beta-D$-glucopyranoside. A glycosidation shift was observed for $\mathrm{C}-3_{\mathrm{Agl}}(\delta$ 77.6), a downfield shift from $\delta$ 66.9. The HMBC spectrum showed key correlation peaks between the proton signal at $\delta 4.98(\mathrm{H}-1 \mathrm{Glc})$ and the carbon resonance at $\delta 77.6(\mathrm{H}-3 \mathrm{Agl})$. On the basis of the above results, the structure of chamaedroside A was deduced as 3-O- $\beta$-D-glucopyranoside-(25S)$5 \beta$-spirostan-3 $\beta$-ol (Fig.1). Compound 1 was isolated from Veronica chamaedrys $L$. for the first time and has been previously reported in the literature [19]. 
The ${ }^{1} \mathrm{H}-\mathrm{NMR}$ spectrum of 2 displayed signals for four steroidal methyl groups at $\delta 1.15(3 \mathrm{H}, \mathrm{s}, \mathrm{H}-18), 0.89(3 \mathrm{H}$, $\mathrm{s}, \mathrm{H}-19), 1.50(3 \mathrm{H}, \mathrm{d}, \mathrm{J}=6.0 \mathrm{~Hz}, \mathrm{H}-21)$ and $1.20(3 \mathrm{H}, \mathrm{d}, \mathrm{J}=6.9 \mathrm{~Hz}, \mathrm{H}-27)$, as well as signals for two anomeric protons at $\delta 4.98(1 \mathrm{H}, \mathrm{d}, \mathrm{J}=7.07 \mathrm{~Hz})$ and $4.84(1 \mathrm{H}, \mathrm{d}, \mathrm{J}=7.5 \mathrm{~Hz})$. The above ${ }^{1} \mathrm{H}-\mathrm{NMR}$ data, an acetalic carbon signal at $\delta 110.7$ in the ${ }^{13} \mathrm{C}$-NMR spectrum, indicated chamaedroside $\mathrm{B}$ to be a furostanol saponin with two monosaccharides. The ${ }^{13} \mathrm{C}$ NMR spectrum of 2 showed $\mathrm{C}-5$ at $\delta 36.6, \mathrm{C}-9$ at $\delta 40.3$, and $\mathrm{C}-19$ at $\delta 23.9$, characteristic of $5 \beta$-steroidal sapogenins. On the basis of the HSQC and HMBC correlations, the aglycone moiety of compound 2 was identified as (25S)-5 $\beta$ furostan-3 $\beta, 22 \alpha, 26$-triol. One glycosyl unit was shown to be linked to the C-26 hydroxy group of the aglycone by an HMBC correlation of the anomeric proton at $\delta 4.84$ with $\mathrm{C}-26$ of the aglycone at $\delta 72.2$. The HMBC spectrum also showed key correlation peaks between the proton signal at $\delta 4.98(\mathrm{H}-1 \mathrm{Glc})$ and the carbon resonance at $\delta 77.8(\mathrm{C}-3$ Agl). Thus, chamaedroside B was determined to be 3-O- $\beta$-D-glucopyranoside-(25S)-5 $\beta$-furostan-3 $\beta, 22 \alpha, 26$-triol-26O- $\beta$-D-glucopyranoside (fig.1). Compound 2 was isolated from Veronica chamaedrys L. for the first time and has been previously reported in the literature [20].

Compound 3 was obtained as an amorphous powder. Its HR-ESI-MS showed a major ion peak at $m / z 763.9176$ $(\mathrm{M}+\mathrm{Na})^{+}$, and significant fragments at $\mathrm{m} / z 601(\mathrm{M}+\mathrm{Na}-162)^{+}$, attributable to the loss of a hexose unit. The molecular formula of 3 was determined as $\mathrm{C}_{39} \mathrm{H}_{64} \mathrm{O}_{13}$ by the HR-ESI-MS $\left(\mathrm{m} / z(\mathrm{M})^{+}\right)$. Furthermore, the prominent fragments were observed at $m / z: 578.7(\mathrm{M}-162)^{+}, 416.6(\mathrm{M}-162-162)^{+}$attribute to the sequential loss of two hexose residues, respectively. The ${ }^{1} \mathrm{H}-\mathrm{NMR}$ spectrum of chamaedroside $\mathrm{C}$ showed two singlet methyl signals at $\delta 0.90(3 \mathrm{H}, \mathrm{s}, \mathrm{Me}-18)$ and $1.08(3 \mathrm{H}$, s, Me-19), and two doublet methyl signals at $\delta 1.27$ (3H, d, J=7.0 Hz, Me-27), and 1.33 (3H, d, J=7.2 Hz, Me-21), which were recognized as typical spirostanol saponin methyls. $5 \beta$ configuration was deduced by HMBC correlation between the methyl signal at $\delta 1.08$ (Me-19) and carbon resonances at $\delta 40.2$ (C-9), 36.8 (C-5) and 37.0 (C-1). Moreover, signals for two anomeric protons at $\delta 4.99(1 \mathrm{H}, \mathrm{d}, \mathrm{J}=7.4 \mathrm{~Hz})$ and $5.45(1 \mathrm{H}, \mathrm{d}, \mathrm{J}=7.4 \mathrm{~Hz})$ could be readily assigned. The $\mathrm{J}$ values $(>7 \mathrm{~Hz})$ of two anomeric protons indicated the $\beta$-orientation at the anomeric centre for the hexose. The ${ }^{13} \mathrm{C}$-NMR spectrum of 3 showed two anomeric carbon signals at $\delta 101.9$ and 105.8. The HMBC spectrum showed key correlation peaks between the proton signal at $\delta 4.99(\mathrm{H}-1 \mathrm{Glc})$ and the carbon resonance at $\delta 77.8$ ( $\mathrm{C}-3$ of the aglycone), the proton signal at $\delta 5.45(\mathrm{H}-1 \mathrm{Glc})$ and the carbon resonance at $\delta 78.7(\mathrm{C}-4 \mathrm{Glc})$. On the basis of the above results, the structure of chamaedroside $C$ was determined as 3-O- $\beta$-D-glucopyranosyl $(1 \rightarrow 4)-\beta$-D-glucopyranoside-(25S)-5 $\beta$-spirostan-3 $\beta$-ol. Chamaedroside $\mathrm{C}$ is a new compound earlier indescribable in the literature.

Compound 4 was obtained as a colorless powder. Its HR-ESI-MS showed a major ion peak at $m / z 944.0735$ $(\mathrm{M}+\mathrm{Na})^{+}$and significant fragments at $m / z 782(\mathrm{M}+\mathrm{Na}-162)^{+}$, attributable to the loss of a hexose unit. The molecular formula of 4 was unequivocally established to be $\mathrm{C}_{45} \mathrm{H}_{76} \mathrm{O}_{19}$ by HR-MALDIMS $(\mathrm{m} / z \mathrm{z} 942 \text { [M+Na] }]^{+}$. Positive coloration reactions were observed when 4 was subjected to Ehrlich and Sannie tests, which suggested that $\mathbf{4}$ have a steroidal saponin skeleton. The ${ }^{1} \mathrm{H}-\mathrm{NMR}$ data of chamaedroside E contained two singlet methyl groups at $\delta 1.003$ and 0.89 (each s), two doublet methyl groups at $\delta 1.22(\mathrm{~d}, \mathrm{~J}=7.0 \mathrm{~Hz}$ ) and $1.33(\mathrm{~d}, \mathrm{~J}=7.0 \mathrm{~Hz}$ ) and a methenyl proton at $\delta 4.98(\mathrm{~m})$, attributable to a steroidal aglycone moiety. Furthermore, the furostanol glycosidic nature of chamaedroside E suggested by the strong absorbtion bands at 3300 and $900 \mathrm{~cm}^{-1}$ in the IR spectrum, and a semiketal carbon signal at $\delta 110.63$ in the ${ }^{13} \mathrm{C}-\mathrm{NMR}$ spectrum.

The above ${ }^{1} \mathrm{H}-\mathrm{NMR}$ spectral data and a comparison of the ${ }^{13} \mathrm{C}-\mathrm{NMR}$ signals of the aglycone moiety of chamaedroside

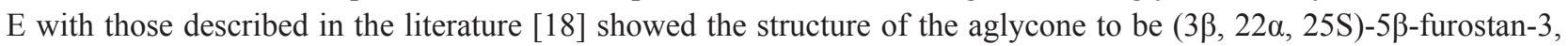
22 , 26-triol. The $\alpha$-configuration of C-22 hydroxyl group of the aglycone moiety was deduced from the semiketal carbon signal at $\delta 110.64$, instead of $\delta 115.5$ for $\beta$-configuration, and it was further confirmed by the ROESY correlation between $\mathrm{H}-20(2.21, \mathrm{dq}, \mathrm{J}=6.5,7.5 \mathrm{~Hz})$ and $\mathrm{H}-23(1.33, \mathrm{~m})$. The $25 \mathrm{~S}$-stereochemistry was established by the resonance of H-27 methyl protons at $\delta 1.22$, a few bigger than 1.00 [18], and also by the resonance difference between equatorial proton signal $(3.48, \mathrm{~m}, \mathrm{~J}=6.5$ and $9.5 \mathrm{~Hz}$ ) and axial proton signal $(4.13, \mathrm{~m})$ of $\mathrm{H}-26: 0.64 \mathrm{ppm}$, a few bigger than 0.57 ppm [18]. $5 \beta$ configuration was deduced by HMBC correlation between the methyl signal at $\delta 1.1$ (Me-19) and carbon resonances at $\delta 40.4(\mathrm{C}-9), 36.7(\mathrm{C}-5)$ and $37.1(\mathrm{C}-1)$.

In the ${ }^{13} \mathrm{C}$-NMR spectrum, among the 45 carbon signals, 27 signals were assignable to the aglycone, the remaining 18 signals were indicative of the presence of three glucose moieties, in good agreement with three anomeric proton signals appearing at $\delta 4.82(\mathrm{~d}, \mathrm{~J}=7.49 \mathrm{~Hz}), 4.98(\mathrm{~d}, \mathrm{~J}=7.07 \mathrm{~Hz}), 5.43(\mathrm{~d}, \mathrm{~J}=7.48 \mathrm{~Hz})$, and the corresponding anomeric carbon signals at $\delta 105.13,101.9$ and 105.9 , respectively.

A sugar chain was determined to be attached to $\mathrm{C}-26$ by an observation of glycosidation shift of $\mathrm{C}-26$ signal from $\delta 66.0$ to 71.4 , and this linkage was further indicated by the cross peak between the ${ }^{13} \mathrm{C}$ signal at $\delta 71.4$ and the anomeric proton signal at $\delta 4.82$ of $\beta$-glucopyranosyl moiety in the HMBC spectrum of 4 .

Similarly, a cross peak between the $\mathrm{C}-3$ signal of aglycone at $\delta 77.91$ and the anomeric proton signal at $\delta 4.98$ in the $\mathrm{HMBC}$ spectrum of 4 , indicated that another sugar chain was located at the $\mathrm{C}-3$ position of aglycone. A $1 \rightarrow 4$ linkage 
of the one sugar moiety to another was revealed by a cross peak between the $\mathrm{C}-4$ signal of the first glucose at $\delta 78.58$ and the anomeric proton signal of the second glucose at $\delta 5.43$ in the HMBC spectrum. The $\beta$-orientation of the anomeric centres of the sugar moieties were supported by the relatively large $\mathrm{J}$ values of their anomeric protons $(\mathrm{J}=7.0-7.8 \mathrm{~Hz})$.

On the basis of all evidences, chamaedroside $E$ was identified as 3-O- $\beta$-D-glucopyranosyl $(1 \rightarrow 4)-\beta$-D-

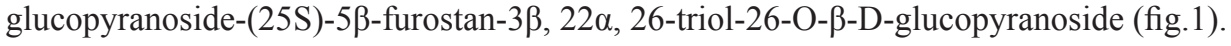

Chamaedroside $\mathrm{E}$ is a new steroidal glycoside isolated and reported for the first time.

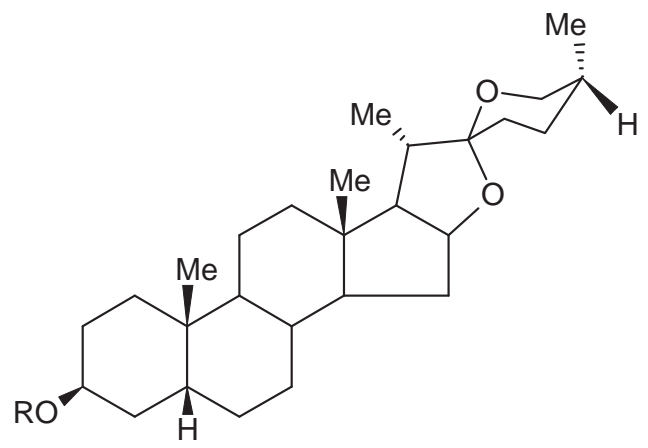

1. $\mathrm{R}=\mathrm{Glc}$

3. $\mathrm{R}=\mathrm{Glc}(1 \rightarrow 4) \mathrm{Glc}$

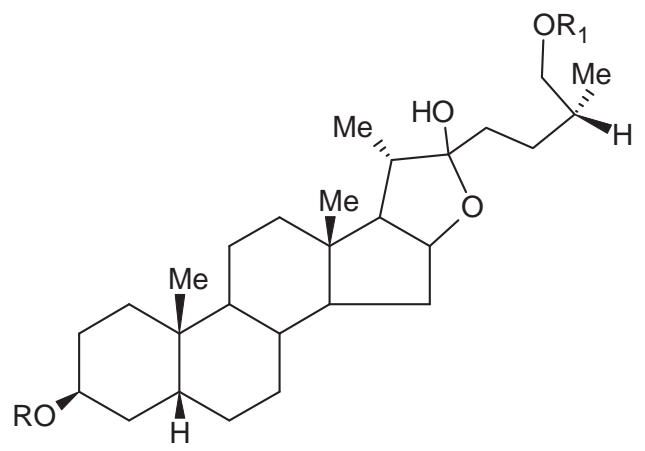

2. $\mathrm{R}=\mathrm{Glc} ; \mathrm{R}_{1}=\mathrm{Glc}$

4. $\mathrm{R}=\mathrm{Glc}(1 \rightarrow 4) \mathrm{Glc} ; \mathrm{R}_{1}=\mathrm{Glc}$

Fig. 1

\section{Experimental}

\section{General experimental procedures}

Melting points were measured on a Boetius table. Optical rotations were recorded with a Perkin-Elmer 243 spectropolarimeter. IR spectra were measured on a Bruker FT-IR IFS 66/s instrument as sample in pressed KBr disks. 1D and 2D NMR spectra were recorded on NMR Bruker Advance $600 \mathrm{MHz}$ spectrometer (Bruker BioSpin GmBH, Rheinstetten, Germany) at $300 \mathrm{~K}$ dissolving all the samples in $\mathrm{C}_{5} \mathrm{D}_{5} \mathrm{~N}$ (Carlo Erba, $99.8 \%$ ). The standard pulse sequence and phase cycling were used for DQF-COSY, HSQC and HMBC spectra. The NMR data were processed using UXNMR software. The chemical shift values are reported as parts per million (ppm) units relative to tetramethylsilane $(\delta 0.00$ ppm in both cases) for ${ }^{1} \mathrm{H}$ and ${ }^{13} \mathrm{C}$, and coupling constants are in hertz (in parentheses).

ESI-MS in the positive ion mode was performed using a Finnigan LCQ Deca ion trap instrument from Thermo Finnigan (San Jose, CA) equipped with Xcalibur software. Samples were dissolved in $\mathrm{MeOH}$ (Baker) and infused in the ESI source by using a syringe pump. The capillary voltage was $43 \mathrm{~V}$, the spray voltage $5 \mathrm{kV}$, and the tube lens offset 30 V. The capillary temperature was $280^{\circ} \mathrm{C}$.

HPLC separations were carried out on a Waters 590 system equipped with a Waters R401 refractive index detector, a Waters XTerra Prep $\mathrm{MSC}_{18}$ column (300 x $7.8 \mathrm{~mm}$ i.d.) and a Rheodyne injector.

TLC was performed on silica gel plates (Merck precoated silica gel $60 \mathrm{~F}_{254}$ ). Gel filtration was performed on the Sephadex G-50 (Loba Feinchemie) and G-25 (Pharmacia, Fine Chemicals). Column chromatography was performed over Silica gel Merck 60 (70-230 mesh, Merck, Chemapol). Solvent systems: chloroform/methanol (4:1), chloroformmethanol-water (65:35:3). All solvents for chromatographic separation were of analytical grade. HPLC grade water $(18 \mathrm{~m} \Omega)$ was prepared using a Millipore Milli-Q purification system (Millipore Corp., Bedford, MA).

Plant material has been collected in the scientific research field of the Institute of Genetics and Plant Physiology in May 2009 year. The voucher specimen has been deposited in the Laboratory of Genetics and Physiology of Plant Stability.

\section{Extraction and separation}

Fresh plant material of Veronica chamaedrys L. (1600 g) was extracted three times at $100^{\circ} \mathrm{C}$ with water for 4 hours. Water extracts were combined and extracted with n-butanol, after that n-butanol was evaporated under reduced pressure to give a mixture of saponins $(10.3 \mathrm{~g})$. This mixture was subjected to purification on Sephadex G-50 and G-25 and then has been chromatographied on silica gel column (70-230 mesh, Merck). The column was eluted with system chloroform-methanol-water (4:1:0-13:7:1). After monitoring by TLC [Si gel plates, chloroform-methanol (4:1)] fractions showing identical characteristics were combined to give A (105 mg) and B (120 mg).

Fractions A and B were submitted to HPLC on a Waters XTerra Prep $\mathrm{MSC}_{18}$ column $(300 \mathrm{x} 7.8 \mathrm{~mm}$ i.d., the flow rate was $1.5 \mu \mathrm{L} / \mathrm{min}$ ), using a $\mathrm{MeOH}: \mathrm{H}_{2} \mathrm{O}$ in the ratio $80: 20$ for $\mathrm{A}$, and $85: 15$ for $\mathrm{B}$ (isocratic conditions). Pure 1 (20.2 $\mathrm{mg})$ and $2(26.6 \mathrm{mg})$ were obtained from $\mathrm{A}, 3(40 \mathrm{mg})$ and $4(52.2 \mathrm{mg})$ from B. 


\section{${ }^{13} \mathrm{C}-\mathrm{NMR}$ spectral data (600 $\left.\mathrm{MHz}, \mathrm{C}_{5} \mathrm{D}_{5} \mathrm{~N}, \mathrm{ppm}\right)$ of glycosides (1-4)}

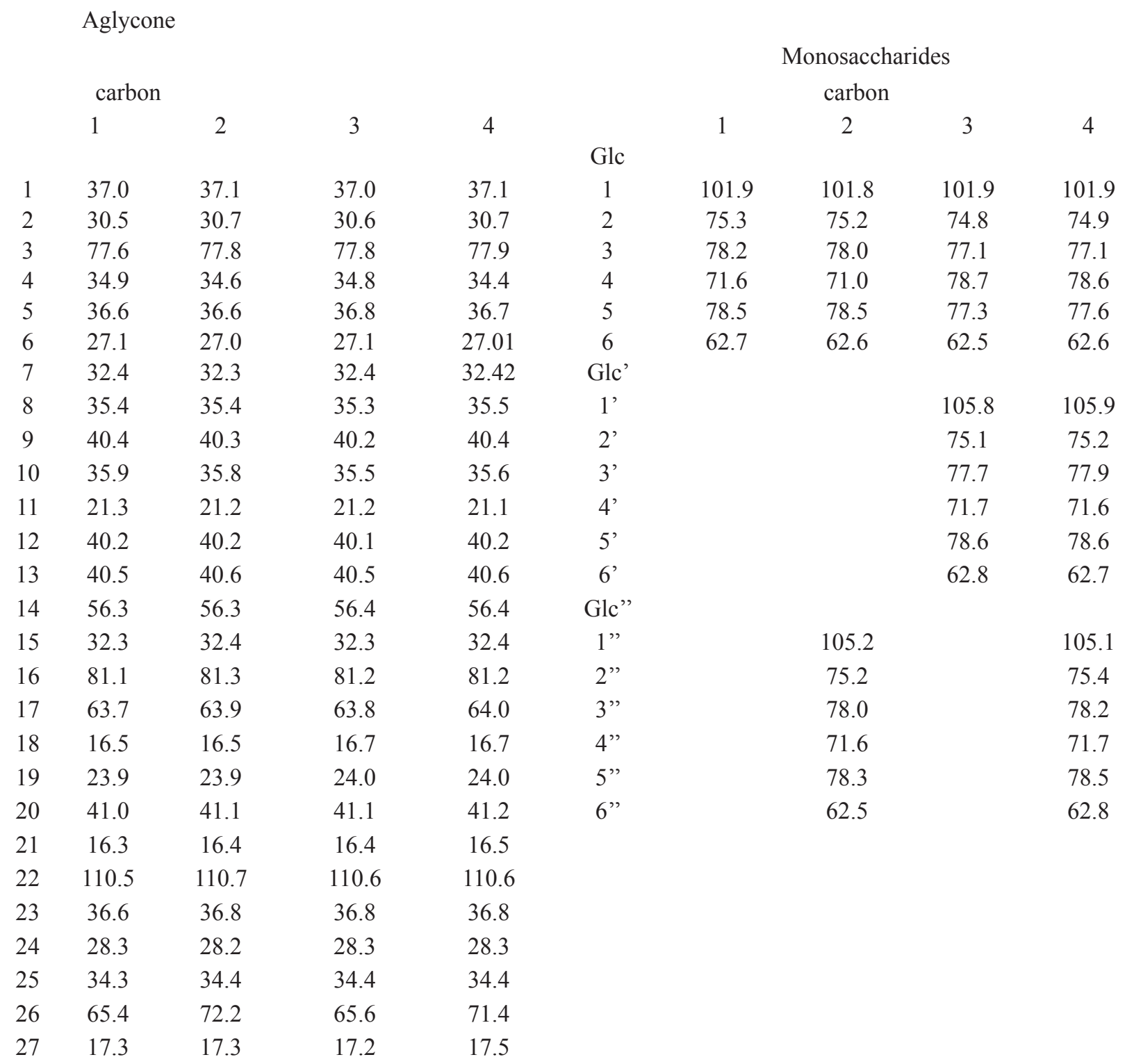

1. Amorphous powder. M. p. $290-292^{\circ} \mathrm{C},[\alpha]^{20}{ }_{\mathrm{D}}:-65\left(\mathrm{CH}_{3} \mathrm{OH}, \mathrm{c} 0.34\right)$. IR $v_{\max }{ }^{\mathrm{KBr}} \mathrm{cm}^{-1}: 3402.5(\mathrm{OH}), 980,910.5$, 850, 757.3 (intensity 915>896, 25S-spiroketal). HR MS, $m / z 578.7771$ [calcd for $\mathrm{C}_{33} \mathrm{H}_{54} \mathrm{O}_{8}(\mathrm{M})^{+}$]; $416.6[\mathrm{M}-162]^{+} ;{ }^{1} \mathrm{H}$ NMR (aglycone) $\delta 4.98(1 \mathrm{H}, \mathrm{m}, \mathrm{H}-16), 4.30(1 \mathrm{H}, \mathrm{m}, \mathrm{H}-3), 1.1(3 \mathrm{H}, \mathrm{s}, \mathrm{Me}-19), 0.89$ (3H, s, Me-18), 1.5 (3H, d, H-21), 4.13 (1H, m, H-26a), 3.48 (1H, m, H-26b), 1.19 (3H, d, Me-27); (sugar) $\delta 4.98$ (d, J=7.07 Hz, H-1 Glc), 4.06 (dd, J=7.5 and $9.0 \mathrm{~Hz}, \mathrm{H}-4 \mathrm{Glc}$ ), 4.11 (dd, $\mathrm{J}=9.0$ and $9.0 \mathrm{~Hz}, \mathrm{H}-3 \mathrm{Glc}$ ), 4.22 (dd, $\mathrm{J}=9.0$ and $9.0 \mathrm{~Hz}, \mathrm{H}-4 \mathrm{Glc}$ ), 3.81 (ddd, $\mathrm{J}=2.5,4.5$ and $9.0 \mathrm{~Hz}, \mathrm{H}-5 \mathrm{Glc}$ ), 4.57 (dd, J=4.5 and $11.5 \mathrm{~Hz}, \mathrm{H}-6 \mathrm{a} \mathrm{Glc}), 4.35$ (dd, J=2.5 and $11.5 \mathrm{~Hz}, \mathrm{H}-6 \mathrm{~b}$ Glc). For ${ }^{13} \mathrm{C}$ NMR data see Table.

2. Amorphous powder. M. p. $183-184^{\circ} \mathrm{C},[\alpha]^{20}{ }_{\mathrm{D}}:-107$ (Py, c 0.34). IR $v_{\max }{ }^{\mathrm{KBr}} \mathrm{cm}^{-1}: 3350(\mathrm{OH}), 900$ (large band). HR MS, $m / z 758.9329$ [calcd for $\left.\mathrm{C}_{39} \mathrm{H}_{67} \mathrm{O}_{14}(\mathrm{M})^{+}\right] ; 596.7[\mathrm{M}-162]^{+} ; 434.6[\mathrm{M}-162-162]^{+} ;{ }^{1} \mathrm{H}$ NMR (aglycone) $\delta 4.96$ (1H, m, H-16), 4.29 (1H, m, H-3), 1.15 (3H, s, Me-19), 0.89 (3H, s, Me-18), 1.5 (3H, d, H-21), 4.132 (1H, m, H-26a), 3.5 (1H, m, H-26b), 1.20 (3H, d, Me-27); (sugars) $\delta 4.98$ (d, J=7.07 Hz, H-1 Glc), 4.26 (dd, J=7.5 and 9.0 Hz, H-2 Glc), 4.13 (dd, J=9.0 and $9.0 \mathrm{~Hz}, \mathrm{H}-3 \mathrm{Glc}$ ), 4.28 (dd, $\mathrm{J}=9.0$ and $9.0 \mathrm{~Hz}, \mathrm{H}-4 \mathrm{Glc}$ ), 3.85 (ddd, J=2.5, 4.5 and 9.0 Hz, H-5 Glc), 4.52 (dd, $\mathrm{J}=4.5$ and $11.5 \mathrm{~Hz}, \mathrm{H}-6 \mathrm{a} \mathrm{Glc}$ ), 4.36 (dd, J=2.5 and $11.5 \mathrm{~Hz}, \mathrm{H}-6 \mathrm{~b}$ Glc). 4.84 (d, J=7.5 Hz, H-1 Glc"), 3.978 (dd, $\mathrm{J}=7.5$ and $9.0 \mathrm{~Hz}, \mathrm{H}-2$ Glc"), 4.216 (dd, J=9.0 and $9.0 \mathrm{~Hz}, \mathrm{H}-3 \mathrm{Glc}$ "), 4.273 (dd, J=9.0 and 9.0 Hz, H-4 Glc"), 3.985 (ddd, J=2.5, 4.5 and 9.0 Hz, H-5 Glc"), 4.559 (dd, J=4.5 and 11.5 Hz, H-6a Glc"), 4.339 (dd, J=2.5 and 11.5 Hz, H-6b Glc"). For ${ }^{13} \mathrm{C}$ NMR data see Table.

3. 
4. Amorphous powder. M. p. $292-294^{\circ} \mathrm{C},[\alpha]^{20}{ }_{\mathrm{D}}:-58\left(\mathrm{CH}_{3} \mathrm{OH}, \mathrm{c} 0.34\right) . \mathrm{IR} v_{\max }{ }^{\mathrm{KBr}} \mathrm{cm}^{-1}: 3398(\mathrm{OH}), 980,914,892$, 850 (intensity 915>896, 25S-spiroketal). HR MS, $m / z$ 740.9176 [calcd for $\left.\mathrm{C}_{39} \mathrm{H}_{64} \mathrm{O}_{13}(\mathrm{M})^{+}\right] ; 578.7[\mathrm{M}-162]^{+} ; 416.6[\mathrm{M}-$ $162-162]^{+}$; ${ }^{1} \mathrm{H}$ NMR (aglycone) $\delta 4.96$ (1H, m, H-16), 4.32 (1H, m, H-3), 1.08 (3H, s, Me-19), 0.90 (3H, s, Me-18), $1.33(3 \mathrm{H}, \mathrm{d}, \mathrm{H}-21), 4.17$ (1H, m, H-26a), 3.5 (1H, m, H-26b), 1.27 (3H, d, Me-27); (sugars) $\delta 4.99$ (d, J=7.4 Hz, H-1 Glc), 4.27 (dd, J=7.5 and 9.0 Hz, H-2 Glc), 4.12 (dd, J=9.0 and $9.0 \mathrm{~Hz}, \mathrm{H}-3 \mathrm{Glc}$ ), 4.25 (dd, J=9.0 and 9.0 Hz, H-4 Glc), 4.27 (ddd, J=2.5, 4.5 and $9.0 \mathrm{~Hz}, \mathrm{H}-5 \mathrm{Glc}$ ), 4.56 (dd, J=4.5 and $11.5 \mathrm{~Hz}, \mathrm{H}-6 \mathrm{a} \mathrm{Glc}$ ), 4.30 (dd, J=2.5 and 11.5 Hz, H-6b Glc). 5.45 (d, J=7.4 Hz, H-1 Glc'), 4.12 (dd, J=7.5 and 9.0 Hz, H-2 Glc'), 4.10 (dd, J=9.0 and 9.0 Hz, H-3 Glc'), 4.21 (dd, $\mathrm{J}=9.0$ and $9.0 \mathrm{~Hz}, \mathrm{H}-4 \mathrm{Glc}$ '), 3.48 (ddd, $\mathrm{J}=2.5,4.5$ and $9.0 \mathrm{~Hz}, \mathrm{H}-5 \mathrm{Glc}$ '), 4.56 (dd, J=4.5 and 11.5 Hz, H-6a Glc'), 4.28 (dd, J=2.5 and $11.5 \mathrm{~Hz}, \mathrm{H}-6 \mathrm{~b}$ Glc'). For ${ }^{13} \mathrm{C}$ NMR data see Table.

5. Amorphous powder. M. p. $187-189^{\circ} \mathrm{C},[\alpha]^{20}{ }_{\mathrm{D}}:-76\left(\mathrm{H}_{2} \mathrm{O}, \mathrm{c} 0.34\right) . \mathrm{IR} v_{\max }^{\mathrm{KBr}} \mathrm{cm}^{-1}: 3300(\mathrm{OH}), 900$ (large band). HR MS, $m / z 921.0735$ [calcd for $\mathrm{C}_{45} \mathrm{H}_{76} \mathrm{O}_{19}(\mathrm{M})^{+}$]; $758.9[\mathrm{M}-162]^{+} ; 596.7[\mathrm{M}-162-162]^{+} ;{ }^{1} \mathrm{H}$ NMR (aglycone) $\delta 4.98$ $(1 \mathrm{H}, \mathrm{m}, \mathrm{H}-16), 4.28$ (1H, m, H-3), 1.003 (3H, s, Me-19), 0.89 (3H, s, Me-18), 1.33 (3H, d, H-21), 4.128 (1H, m, H-26a), 3.48 (1H, m, H-26b), 1.22 (3H, d, Me-27); (sugars) $\delta 4.98$ (d, J=7.07 Hz, H-1 Glc), 4.26 (dd, J=7.5 and 9.0 Hz, H-2 Glc), 4.10 (dd, J=9.0 and $9.0 \mathrm{~Hz}, \mathrm{H}-3 \mathrm{Glc}$ ), 4.24 (dd, J=9.0 and $9.0 \mathrm{~Hz}, \mathrm{H}-4 \mathrm{Glc}$ ), 4.27 (ddd, J=2.5, 4.5 and 9.0 Hz, H-5 Glc), 4.58 (dd, J=4.5 and $11.5 \mathrm{~Hz}, \mathrm{H}-6 \mathrm{a} \mathrm{Glc}$ ), 4.34 (dd, J=2.5 and $11.5 \mathrm{~Hz}, \mathrm{H}-6 \mathrm{~b}$ Glc). 5.43 (d, J=7.48 Hz, H-1 Glc'), 4.12 (dd, J=7.5 and 9.0 Hz, H-2 Glc'), 4.10 (dd, J=9.0 and 9.0 Hz, H-3 Glc'), 4.22 (dd, J=9.0 and $9.0 \mathrm{~Hz}, \mathrm{H}-4$ Glc'), 3.50 (ddd, J=2.5, 4.5 and 9.0 Hz, H-5 Glc'), 4.56 (dd, J=4.5 and 11.5 Hz, H-6a Glc'), 4.27 (dd, J=2.5 and 11.5 Hz, H-6b Glc'). 4.82 (d, J=7.49 Hz, H-1 Glc"), 3.98 (dd, J=7.5 and 9.0 Hz, H-2 Glc"'), 4.22 (dd, J=9.0 and 9.0 Hz, H-3 Glc"), 4.26 (dd, J=9.0 and $9.0 \mathrm{~Hz}, \mathrm{H}-4$ Glc"), 3.98 (ddd, J=2.5, 4.5 and $9.0 \mathrm{~Hz}, \mathrm{H}-5$ Glc"), 4.53 (dd, J=4.5 and $11.5 \mathrm{~Hz}$, H-6a Glc"), 4.34 (dd, J=2.5 and $11.5 \mathrm{~Hz}, \mathrm{H}-6 \mathrm{~b}$ Glc"). For ${ }^{13} \mathrm{C}$ NMR data see Table.

\section{Conclusion}

Two steroidal glycosides of spirostane series chamaedroside A and chamaedroside C, and two steroidal glycosides of furostane series chamaedroside $\mathrm{B}$ and $\mathrm{E}$ have been isolated for the first time from the plants of Veronica chamaedrys $L$. During the investigation the structure of chamaedroside A was elucidated as 3-O- $\beta$-D-glucopyranoside-(25S)$5 \beta$-spirostan-3 $\beta$-ol, chamaedroside B - 3-O- $\beta$-D-glucopyranoside-(25S)-5 $\beta$-furostan-3 $\beta, 22 \alpha, 26$-triol-26-O- $\beta$-Dglucopyranoside, chamaedroside $\mathrm{C}-3$-O- $\beta$-D-glucopyranosyl $(1 \rightarrow 4)-\beta$-D-glucopyranoside-(25S)-5 $\beta$-spirostan-3 $\beta$-ol and chamaedroside E - 3-O- $\beta$-D-glucopyranosyl ( $1 \rightarrow 4)-\beta$-D-glucopyranoside-(25S)-5 $\beta$-furostan-3 $\beta, 22 \alpha$, 26 -triol26-O- $\beta$-D-glucopyranoside. Chamaedrosides $\mathrm{C}$ and $\mathrm{E}$ are new compounds, and chamaedrosides $\mathrm{A}$ and $\mathrm{B}$ are known steroidal glycosides identified in Veronica chamaedrys L. plants for the first time.

\section{Acknowledgments}

The authors are grateful to the members of the analytical group of Department of Chemistry, Adam Mickiewicz University in Poznan, for recording the IR and MS experiments.

\section{References}

[1]. Lahloub, M. F. Thesis, ETH Nr. 7340, Zurich 1983.

[2]. Socolov, P.D. Rastitelinie resursi. «Nauka».1990, pp. 173-182.

[3]. Tomassini, L.; Brkic, D.; Serafini, M. Fitoterapia 1995, 66, 382.

[4]. Su, B.; Zhu, Q.; Jia, Z. Tetrahedron Lett. 1999, 40, 357-358.

[5]. Graham, J.G. J. Ethnopharmacol. 2000, 73, 347-377.

[6]. Lahloub, M. F.; Zaghloul, M. G.; Afifi, M. S.; Sticher, O. Phytochemistry 1993, 33, 401-405.

[7]. Taskova, R.; Handjieva, N.; Peev, D.; Popov, S. Phytochemistry 1998, 49,1323-1327.

[8]. Taskova, R.; Handjieva, N.; Evstatieva, L.; Popov, S. Phytochemistry 1999, 52,1443-1445.

[9]. Ozipek, M.; Saracoglu, I.; Kojima, K.; Ogihara, Y.; Calis, I. Chem. Pharm. Bull. 1999, 47, 561-562.

[10]. Aoshima, H.; Miyase, T.; Ueno, A. Phytochemistry 1994, 37, 547-550.

[11]. Saracoglu, I.; Harput, U.; Inoue, M.; Ogihara, Y. Chem. Pharm. Bull. 2002, 50, 665-668.

[12]. Chari, V. M.; Grayer-Barkmeijer, R.J.; Harborne, J.B.; Osterdahl, B. G. Phytochemistry 1981, 20, $1977-1979$.

[13]. Harput, S.; Saracoglu, I.; Ynoue, M.; Ogihara, Y. Chem.Pharm.Bull. 2002, 50, 869 - 871.

[14]. Marchenko A.; Kintia, P.; Mashcenco, N.; Basarello, C.; Piacente, S.; Pizza, C. Chem. J. Mold. 2008, 3(2), 101-104.

[15]. Sannie, C.; Lapin, H.; Heitz, S. Compt. Rend. 1952, 1082.

[16]. Kiyosawa, S.; Huton, M. Chem. Pharm. Bull. 1968, 16, 1162.

[17]. Agrawal, P.K.; Jain, D.C.; Gupta, R.K.; Thakur, R.S. Phytochemistry 1985, 24, 2479-2496.

[18]. Agrawal, P.K.; Jain, D.C.; Pathak, A.K. Magn. Reson. Chem. 2004, 42, 990-993.

[19]. Tori, K.; Seo, S.; Terui, Y.; Nishikawa, J.; Yasuda, F. Tetrahedron Lett. 1981, 22, 2405-2408.

[20]. Hostettmann, K.; Marston, A. Saponins 1995, 548. 